\title{
PENGARUH LAMA PENYANGRAIAN MANUAL TERHADAP KARAKTERISTIK KAKAO BUBUK
}

\author{
Sri Wijanarti ${ }^{1}$, Annie Mufyda Rahmatika ${ }^{2}$, Ratih Hardiyanti ${ }^{3}$ \\ 1.2.3 Program Studi Agroindustri, Departemen Teknologi Hayati \\ dan Veteriner, Sekolah Vokasi, Universitas Gadjah Mada, Indonesia \\ Email: ${ }^{1}$ sriwijanarti@ugm.ac.id ; ${ }^{2}$ annie.rahmatika@ugm.ac.id; ${ }^{3}$ ratih.hardi@ugm.ac.id
}

\begin{abstract}
Cacao powder is one of derivative products of cacao, applied in many industries such as chocolate drink, confectionary, bakery, etc cacao powder demand increased year by year. Cocoa powder aroma and taste are determined by cacao processing stages, especially roasting. Maillard reaction occurs during roasting, produces aroma and taste compounds. The purpose of this study was to evaluate the effect of roasting to cocoa powder characteristics. The study was conducted by roasting cocoa bean using manual equipment at $135^{\circ} \mathrm{C}$ in different time interval which were 5, 10, and 15 minutes. The results were compared to 40 minutes roasted cocoa bean using roaster at $135^{\circ} \mathrm{C}$ as control. Then the cocoa bean was further processed into cocoa powder. The cocoa powder was used to analyze the physicochemical and organoleptics characteristics. Optimum roasting time was obtained by 15 minutes roasting based on physichochemical and preference test.
\end{abstract}

Keywords: roasting, cacao powder, cocoa bean, quality product

\section{PENDAhULUAN}

Coklat bubuk adalah salah satu produk turunan dari kakao yang diaplikasikan secara luas di indusri pangan, antara lain dalam produk minuman coklat, produk konfeksioneri, produk bakeri, dan lain sebagainya. Aroma dan cita rasa coklat bubuk sangat ditentukan oleh rangkaian tahap pengolahan kakao terutama di proses penyangraian. Selama penyangraian, terjadi reaksi Maillard di mana terbentuk senyawasenyawa aroma dan cita rasa coklat bubuk.

Kakao telah diolah menjadi berbagai jenis makanan dan minuman yang sangat bervariasi. Sebagai negara pengekpor biji kakao terbesar ketiga di dunia, Indonesia mensuplai 387,8 ribu ton ke pasar dunia (Pusat Penelitian Kakao dan Kopi Indonesia, 2015). Indonesia masih menggantungkan industri kakao pada ekspor kakao non-olahan (biji kakao). Industri pengolahan kakao masih kecil apabila dibandingkan dengan jumlah produksi bahan bakunya (biji kakao). Padahal, apabila dilihat dari aspek nilai tambahnya, biji kakao kering merupakan produk kakao dengan nilai tambah yang 
paling rendah. Pengolahan biji kakao menjadi produk primer seperti pasta kakao, bubuk kakao, atau lemak kakao serta produk sekunder seperti coklat atau coklat bubuk, mampu meningkatkan nilai tambah kakao secara signifikan.

Pemerintah mulai menginisiasi kebijakan hilirisasi kakao pada tahun 2008. Kebijakan ini cukup efektif dalam meningkatkan industri pengolahan kakao di Indonesia, dari 130.000 ton pada tahun 2009 menjadi 306.500 ton pada tahun 2011 (Pusat Penelitian Kakao dan Kopi Indonesia, 2015). Peningkatan yang siginifikan ini merupakan indikator positif tentang perkembangan industri pengolahan kakao di Indonesia. Tantangan terbesar yang harus dihadapi untuk dapat bersaing dengan produk yang ada di pasar adalah kualitas produk kakao yang dihasilkan serta produk turunannya.

Coklat bubuk adalah salah satu produk turunan dari kakao yang diaplikasikan secara luas di indusri pangan, antara lain dalam produk minuman coklat, produk konfeksioneri, produk bakeri, dan lain sebagainya. Bubuk kakao berfungsi sebagai ingredien atau agen pemberi rasa coklat. Selain itu, bubuk kakao berperan penting dalam pembentukan warna, densitas, viskositas, dan mouthfeel produk. Permintaan pasar terhadap coklat bubuk meningkat dari tahun ke tahun baik di Indonesia maupun luar negeri (Anonim, 2014).

Parameter kualitas bubuk coklat yang terpenting berdasarkan SNI 3747 : 2009 adalah bau, rasa, dan warna. Aroma khas coklat merupakan hasil dari reaksi kompleks yang berkesinambungan selama proses pengolahan biji kakao. Proses fermentasi biji kakao menghasilkan prekursor-prekursor aroma. Senyawa prekursor ini bereaksi melalui reaksi pencoklatan non-enzimatis Maillard menghasilkan aroma coklat ketika disangrai (Puziah et al., 1998). Proses penyangraian sangat krusial dalam pengolahan kakao karena memiliki fungsi yang kompleks. Selain untuk mengembangkan aroma, penyangraian juga menentukan rasa, warna, dan kadar air biji kakao. Parameter yang berpengaruh dalam penyangraian adalah waktu dan suhu sangrai.

Aroma dan cita rasa rasa kakao terbentuk pada tahap selanjutnya, yaitu penyangraian. Kombinasi suhu dan waktu yang optimum dapat menghasilkan biji kakao dengan aroma kuat dan rendemen yang tetap tinggi. Biji kakao dengan penyangraian tidak sempurna (under-roasted) memiliki rendemen yang tinggi namun memiliki aroma coklat lemah karena reaksi Maillard tidak dapat berjalan dengan baik 
untuk menghasilkan senyawa-senyawa aroma. Sebaliknya, over-roasted mengakibatkan aroma biji kakao hilang digantikan dengan aroma asap/gosong dan rendemen rendah.

Penyangraian bertujuan untuk membentuk aroma kakao, menurunkan kadar air hingga 5-6\%, dan mengurangi kandungan mikrobia yang berasal dari proses fermentasi. Fungsi yang paling krusial dari penyangraian adalah pembentukan aroma dan cita rasa kakao yang dihasilkan. Proses penyangraian dilakukan pada suhu tinggi agar reaksi Maillard dapat berlangsung. Kisaran suhu yang digunakan adalah $90^{\circ} \mathrm{C}$ hingga $140^{\circ} \mathrm{C}$. Suhu dan lama penyangraian menentukan keberhasilan proses penyangraian. Ginting (2011) melaporkan bahwa penyangraian biji kakao pada suhu $90^{\circ} \mathrm{C}$ selama 50 menit menghasilkan coklat bubuk dengan karakteristik dan sifat organoleptik terbaik. Sedangkan, Sewet (2004) telah melakukan penelitian sebelumnya dengan menyangrai biji kakao pada berbagai suhu dan mendapatkan bahwa suhu $140^{\circ} \mathrm{C}$ selama 20 menit menghasilkan coklat bubuk dengan penerimaan yang terbaik. Semakin tinggi suhu yang digunakan, semakin pendek waktu yang dibutuhkan untuk membentuk aroma dan cita rasa kakao. Namun belum ada penelitian yang melaporkan hasil penyangraian dari suhu yang lebih tinggi dan waktu yang lebih pendek. Oleh karena itu, perlu dikaji lebih lanjut untuk melihat pengaruh penyangraian pada berbagai variasi suhu tinggi terhadap karakteristik fisikokimia dan organoleptik coklat bubuk yang dihasilkan. Hasil akhir penyangraian adalah biji kakao sangrai yang telah memiliki aroma dan cita rasa coklat. Produk ini siap untuk tahap pengolahan selanjutnya menjadi berbagai produk turunan coklat.

\section{BAHAN DAN METODE PENELITIAN}

\section{Bahan}

Penelitian ini menggunakan biji kakao yang telah difermentasi dan dikeringkan. Biji kakao berasal dari Desa Banjaroyo, Kalibawang, Kulon Progo, D.I.Yogyakarta.

\section{Metode Penelitian}

Penelitian ini dibagi menjadi 2 tahapan, yakni (1) proses pembuatan bubuk kakao dengan variasi lama penyangraian dan (2) analisis karakteristik bubuk kakao meliputi fisikokimia dan sensoris. Pada pembuatan bubuk kakao, proses penyangraian dilakukan secara manual menggunakan teflon dan kompor gas dengan variasi waktu yang berbeda. Selain itu, dilakukan proses penyangraian menggunakan mesin penyangrai 
berputar dengan menggunakan udara panas. Biji kakao yang disangrai menggunakan mesin sangrai berputar dijadikan sebagai control.

Pada proses pembuatan bubuk kakao diawali dengan cara menyangrai 500 gram biji kakao kering pada suhu awal teflon $135^{\circ} \mathrm{C}$ dan dilakukan 3 variasi waktu penyangraian yang berbeda (5,10 dan 15 menit). Selama proses penyangraian, dilakukan pengadukan secara berkelanjutan menggunakan gagang kayu dan panas api dijaga konstan. Setelah dilakukan proses penyangraian, biji kakao didiamkan pada suhu ruang kemudian dilakukan proses pengupasan cangkang biji kakao sehingga diperoleh nib kakao. Nib kakao ini dihaluskan menjadi pasta menggunakan blender Philips HR 2111 yang dilakukan dengan teknik pulse selama 15 menit. Setelah itu dilakukan proses pengempaan dengan menggunakan mesin pengempa mekanis dengan beban 10 ton. Cake hasil pengempaan dialkalisasi menggunakan $\mathrm{NaHCO}_{3}$ dan $\mathrm{NaCl}$. Bubuk kakao yang telah dialkalisasi ini dihaluskan dan diayak untuk menghasilkan bubuk kakao 80 mesh.

\section{Analisis Kimia}

\section{Analisis Lemak}

Analisis lemak dilakukan dengan cara dilakukan proses hidrolisa terlebih dahulu kemudian dilakukan proses ekstraksi lemak. Pertama, menimbang 4-5 g contoh kemudian menambahkan $45 \mathrm{~mL}$ air suling mendidih secara perlahan sambil diaduk hingga homogen. Kemudian menambahkan $55 \mathrm{~mL} \mathrm{HCl} 8 \mathrm{M}$ lalu campuran tersebut dididihkan perlahan-lahan selama 15 menit dalam system tertutup. Lalu disaring dan dilakukan pencucian. Selanjutnya dikringk,an dalam oven pada suhu $105^{\circ} \mathrm{C}$ selama 18 jam. Selanjutnya selongsong kertas saring berisi bubuk kakao diekstrak lemaknya menggunakan soxhlet dengan pelarut petroleum ether selama 4 jam.

\section{Analisis Aktivitas Antioksidan menggunakan Uji DPPH}

Uji DPPH dilakukan berdasarkan prosedur yang telah dilakukan oleh $\mathrm{Hu}$ et al. (2016). Larutan DPPH dibuat dengan melarutkan kristal DPPH dalam methanol 80\% menghasilkan larutan DPPH 0,1 mM. Larutan DPPH kemudian disimpan di tempat gelap dan suhu dingin hingga digunakan. Absorbansi larutan DPPH ditera pada panjang gelombang $517 \mathrm{~nm}$ untuk mendapatkan panjang gelombang blanko. Sebanyak 0,5 mL sampel yang telah disaring, ditambahkan dengan 2,95 $\mathrm{mL}$ aquades, dikocok hingga 
tercampur sempurna, dan disimpan di tempat gelap pada suhu $23^{\circ} \mathrm{C}$ selama 30 menit. Absorbansi akhir ditera pada $517 \mathrm{~nm}$. Aktivitas antioksidan ditunjukkan sebagai \%inhibisi, yaitu penurunan nilai absorbansi larutan DPPH dengan rumus sebagai berikut.

$$
\% \text { inhibisi }=((\text { Ao }-\mathrm{A}) / \mathrm{Ao}) \times 100 \%
$$

Di mana Ao : absorbansi blanko

A : absorbansi sampel

\section{Analisis Sensoris}

Uji sensoris ini dilakukan untuk melakukan pengujian kualitatif yang digunakan untuk menentukan lama penyangraian optimum berdasarkan tingkat kesukaan panelis. Pengujian ini dilakukan menggunakan 30 panelis yang berusia 20-25 tahun, tidak memiliki alergi terhadap coklat, dan menyukai coklat. Analisis sensoris dilakukan menggunakan Uji Kesukaan atau Preference Test untuk mengetahui tingkat kesukaan dan tingkat penerimaan panelis terhadap produk yang dihasilkan.

Panelis diminta untuk memberikan penilaian berdasarkan tingkat kesukaannya terhadap 4 sampel yang disediakan. Sampel yang diujikan adalah bubuk kakao yang dibuat dari biji kakao sangrai 5 menit, 10 menit, 15 menit, dan kontrol. Pada uji kesukaan, panelis diminta untuk menilai tingkat kesukaan berdasarkan nilai 1 (sangat tidak suka), 2 (tidak suka), 3 (agak tidak suka), 4 (netral), 5 (agak suka), 6 (suka), dan 7 (sangat suka). Data yang diperoleh kemudian dianalisa menggunakan ANOVA diteruskan dengan Uji Duncan untuk mengetahui tingkat signifikansi perbedaan antar sampel.

\section{HASIL DAN PEMBAHASAN}

\section{Pengaruh Penyangraian terhadap Kandungan Lemak Bubuk Kakao}

Coklat bubuk adalah salah satu produk turunan dari kakao. Biji kakao sangrai dikupas kulit biji kemudian dipasta. Dari pasta kakao dapat diolah menjadi 2 produk yaitu produk coklat (permen, coklat batang dll), cocoa butter, dan coklat bubuk (Pusat Penelitian Kopi dan Kakao, 2015). Berdasarkan SNI 3747-2009, coklat bubuk adalah produk yang diperoleh dari bungkil kakao yang diubah bentuknya menjadi bubuk. 
Bungkil kakao (cocoa press cake) diperoleh dari kakao pasta yang telah dihilangkan sebagian lemaknya dengan atau tanpa proses alkalisasi.

Pasta cokelat atau cocoa mass dibuat dari biji kakao kering melalui beberapa tahapan proses untuk mengubah biji yang kakao yang semula padat menjadi semi cair atau cair. Setiap ton pasta cokelat membutuhkan 1,20 - 1,25 ton biji kakao kering. Pasta cokelat dapat diproses lebih lanjut menjadi lemak dan bubuk cokelat yang merupakan bahan baku utama berbagai produk makanan atau minuman cokelat. Untuk dapat digunakan sebagai bahan baku makanan dan minuman, nib yang semula berbentuk butiran padat kasar harus dihancurkan sampai ukuran tertentu $(<20 \mathrm{~m} \mu)$ dan menjadi bentuk pasta cair kental. Proses pemastaan atau penghalusan nib kakao umumnya dilakukan dengan cara penghancuran untuk merubah biji kakao padat menjadi pasta dengan kehalusan butiran $40 \mathrm{~m} \mu$ dengan menggunakan mesin silinder (Mulato, 2005).

Lebih dari setengah berat nib adalah lemak, efek dari penghalusan (pemastaan), bersama dengan panas yang terbentuk dari proses penghalusan, menyebabkan nib yang padat menjadi cair, dan akan memadat jika temperatur turun di bawah titik lelehnya. Derajat kehalusan ukuran partikel sangat penting. Liquor yang digunakan untuk pembuatan lemak kakao dan bubuk, jika terlalu halus akan sulit untuk dipress. Namun, jika terlalu kasar pengeperesan tidak akan sempurnah dikarenakan sejumlah lemak masih terjebak dalam struktur sel. (Mulato,2005).

Pasta kakao yang telah dipres atau dihilangkan sebagian lemaknya kemudian dikeringkan dan dihaluskan. Ukuran butir coklat bubuk yang dipersyaraktan dari standar nasional Indonesia (SNI) adalah 200 mesh. Lama penyangraian dapat mempengaruhi kandungan lemak pada bubuk kakao sebagaimana yang ditampilkan pada Gambar 1. Penyangraian selama 10 dan 15 menit memiliki kesamaan secara statistic serta berbeda nyata dengan control. Selama penyangraian terjadi penghilangan air dan lemak dari pasta kakao. Lama penyangraian yang optimum dapat menghasilkan bubuk kakao dengan kandungan lemak yang rendah sesuai dengan SNI. 


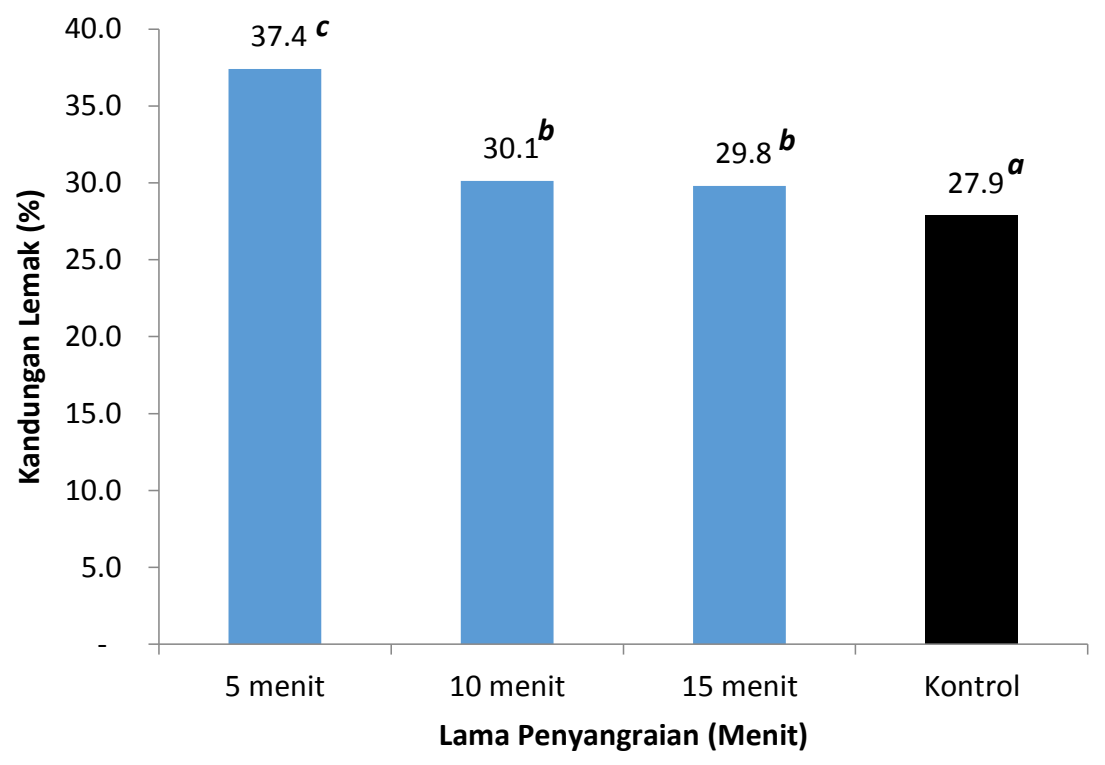

Gambar 1. Grafik Pengaruh Penyangraian Terhadap Kandungan Lemak Bubuk Kakao

\section{Pengaruh Penyangraian terhadap Aktivitas Antioksidan Bubuk Kakao}

Kakao mengandung berbagai nutrisi seperti lemak, karbohidrat, serat, asam organic, serta senyawa aktif yang merupakan hasil metabolism sekunder. Senyawa aktif yang dominan dan telah banyak dilaporkan adalah senyawa polifenol yang memiliki aktivitas antioksidan.

Selama penyangraian, biji kakao mengalami pemanasan yang dapat menyebabkan terjadinya perubahan fisikokimia dari komponen-komponen di dalamnya. Biji kakao mengandung senyawa polifenol yang memiliki aktivitas antioksidan. Senyawa tersebut sebagian besar berawal dari golongan senyawa flavonoid dan alkaloid (alkali). Senyawa-senyawa ini memberikan rasa sedikit sepat dan pahit pada biji kakao mentah. Flavonoid yang paling dominan pada biji kakao adalah jenis epikatekin $\left(\mathrm{C}_{15} \mathrm{H}_{14} \mathrm{O}_{6}\right)$ yang termasuk dalam senyawa polifenol dan bersifat antioksidan, sedangkan dari golongan alkaloid berupa senyawa theobromin $\left(\mathrm{C}_{7} \mathrm{H}_{8} \mathrm{O}_{2} \mathrm{~N}_{4}\right)$. Gula pereduksi yang pada akhirnya disintesis menjadi flavonoid dan alkaloid merupakan jenis gula dengan gugus aldehid (-OH) seperti yang terdapat pada glukosa atau galaktosa, pada biji kakao senyawa tersebut tersimpan di dalam komponen karbohidrat.

Hasil penelitian menunjukkan bahwa semakin lama penyangraian, aktivitas antioksidan meningkat secara signifikan (Gambar 2). Hal ini dapat disebabkan oleh pemanasan selama penyangraian memicu adanya degradasi polifenol serta reaksi Maillard antara protein dan polifenol menghasilkan melanoidin yang berpotensi sebagai 
penangkal radikal bebas. Selain itu, pemanasan menyebabkan kerusakan membrane sel dan dinding sel sehingga melepaskan senyawa fenolik dari ikatan ester yang bersifat tidak larut (Dewanto, et al., 2002).

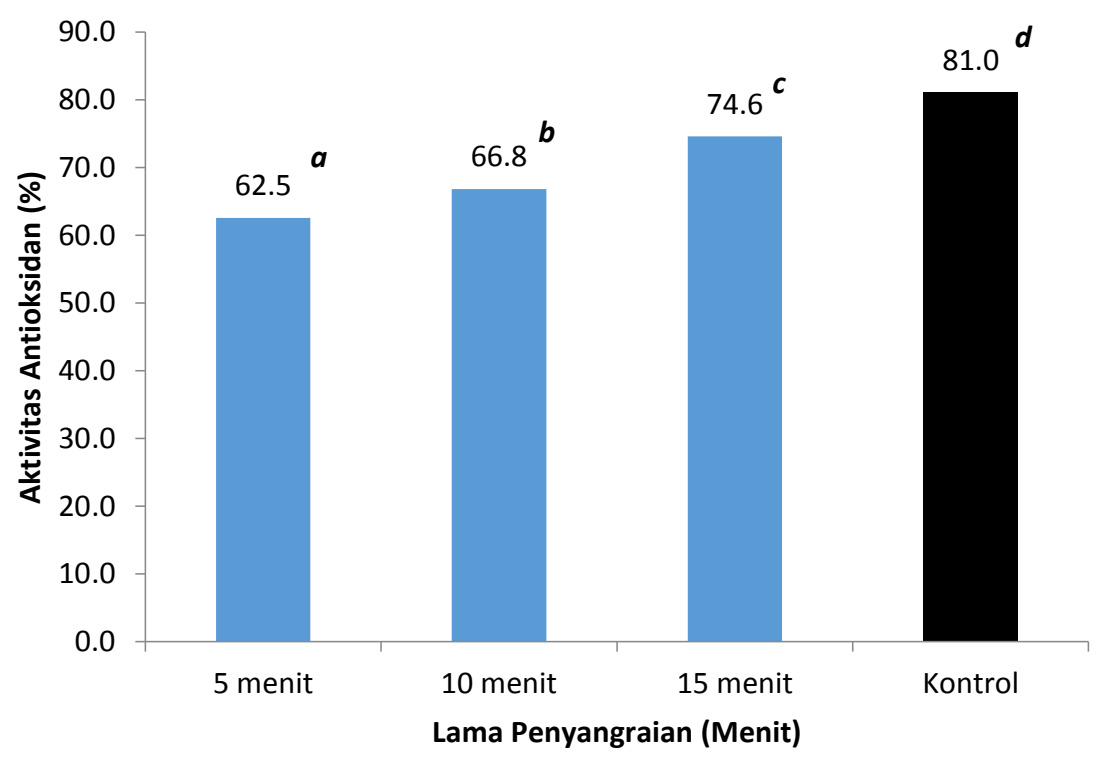

Gambar 2. Grafik Pengaruh Penyangraian Terhadap Aktivitas Antioksidan Bubuk Kakao

Pengaruh lama penyangraian terhadap aktivitas antioksidan diplotkan pada grafik berikut ini (Gambar 3). Berdasarkan data yang diperoleh dari penyangraian manual, diperoleh persamaan garis :

$$
Y=0.0701 x^{2}-0.2013 x+61.79
$$

Berdasarkan persamaan ini, untuk mendapatkan aktivitas antioksidan yang mendekati dengan control maka perlu dilakukan penyangraian secara manual selama 18 menit. 


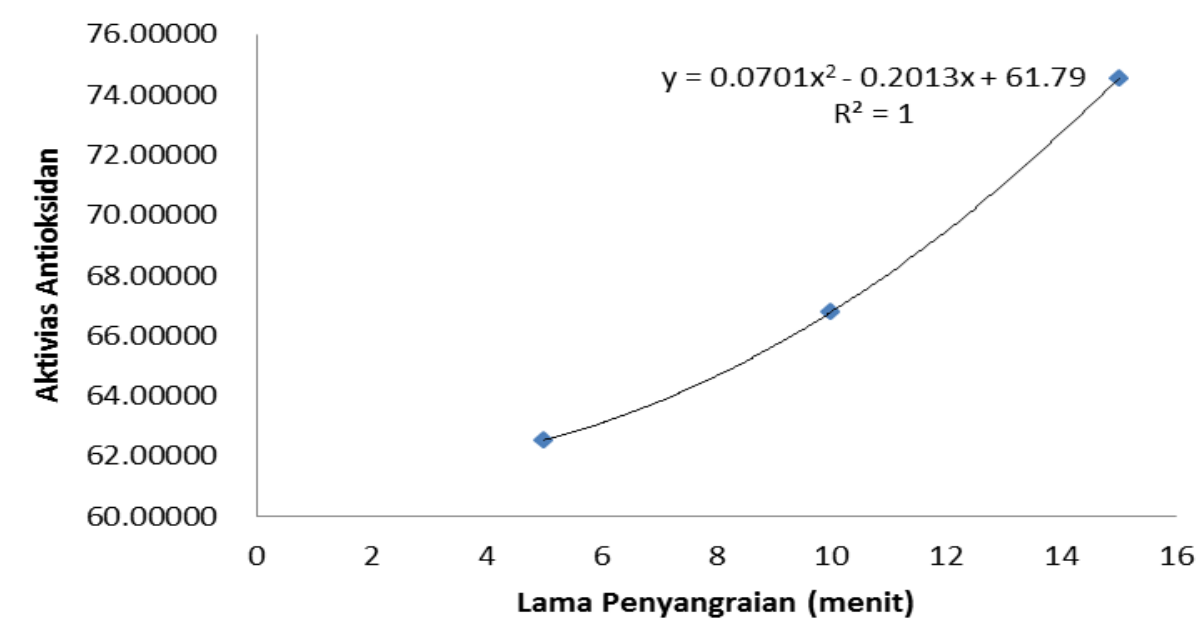

Gambar 3. Model Pengaruh Penyangraian Terhadap Aktivitas Antioksidan Bubuk Kakao

\section{Pengaruh Penyangraian terhadap Uji Kesukaan Bubuk Kakao}

Uji kesukaan bubuk kakao dilakukan pada 30 panelis yang menyukai kakao dan tidak memiliki alergi terhadap kakao. Hasil menunjukkan bahwa penyangraian mempengaruhi warna bubuk kakao secara signifikan namun tidak berpengaruh secara signifikan terhadap tekstur bubuk kakao (Tabel 1).

\section{Tabel 1. Tingkat kesukaan panelis terhadap bubuk kakao}

\begin{tabular}{lcc}
\hline Sampel & Warna & Tekstur \\
\hline 5' sangrai & $4.6^{\mathrm{a}}$ & $5.1^{\mathrm{a}}$ \\
$10^{\prime}$ sangrai & $4.4^{\mathrm{a}}$ & $4.8^{\mathrm{a}}$ \\
$15^{\prime}$ sangrai & $5.5^{\mathrm{b}}$ & $4.9^{\mathrm{a}}$ \\
Kontrol & $4.6^{\mathrm{b}}$ & $5.2^{\mathrm{a}}$ \\
\hline
\end{tabular}

Senyawa-senyawa precursor aroma kakao terbentuk pada tahap fermentasi. Pada tahap penyangraian biji kakao mengalami perubahan fisik dan kimia. Perubahan ini disebabkan karena adanya interaksi senyawa prekursor pembentuk cita rasa melalui reaksi Maillard. Berbagai jenis asam amino dan gula pereduksi akan menghasilkan senyawa melanoidin dan senyawa non-volatil. Selain itu, terbentuk pula lebih dari 3.500 senyawa volatil yang merupakan senyawa pembentuk cita rasa kakao. Komponen prekursor yang berinteraksi melalui reaksi Maillard adalah alkohol, eter, furan, thiazole, pyrone, asam, ester, aldehid, imin, amin, pyrazin, dan pyrole. Senyawa pyrazin yang diproduksi oleh glyoxal dan glisin merupakan senyawa dominan pada aroma kakao 
yang memberi cita rasa berupa sensasi rasa manis, cokelat, karamel, dan sensasi aroma kacang sangrai.

Semakin lama penyangraian menyebabkan warna semakin coklat dan meningkatkan kesukaan panelis. Warna coklat disebabkan adanya reaksi Maillard pada saat penyangraian. Reaksi Maillard adalah reaksi antara asam amino dengan gula pereduksi yang terjadi pada suhu tinggi, di mana gugus karbonil dari glukosa (gula pereduksi) berinteraksi dengan gugus nukleofilik grup amino dari protein dalam suasanan basa sehingga terbentuk kompleks pigmen (melanoidin) yang berwarna cokelat dan senyawa 5-hidroksimetil-2-furfuraldehid (HMF) dengan tahapan reaksi sebagai berikut:

1. Reaksi antara gugus karboksil (gula pereduksi) dengan nitrogen dari asam amino (nucleophilic attack) sehingga membentuk glikosamin dengan reaksi bolak balik pada $\mathrm{pH}$ rendah.

2. Glikosamin akan menghasilkan produk amadori menurut reaksi Amadori berupa gula yang terdiri dari 1 amino dan 2 ketosa (amino ketosa).

3. Dehidrasi dari hasil reaksi Amadori membenruk turunan-turunan furfuraldehida, misalnya dari heksosa diperoleh hidroksi metil furfural.

\section{KESIMPULAN}

Penyangraian mempengaruhi karakteristik bubuk kakao yang dihasilkan. Penyangraian manual selama 15 menit dapat menghasilkan bubuk kakao dengan karakteristik yang mendekati control. Pada kondisi ini, bubuk kakao yang dihasilkan memiliki kandungan lemak, aktivitas antioksidan, dan tingkat penerimaan sensoris yang mendekati dengan kontrol.

\section{UCAPAN TERIMA KASIH}

Penulis mengucapkan terimakasih kepada Dana Masyarakat Sekolah Vokasi Universitas Gadjah Mada yang telah memberikan dukungan dana sehingga penelitian ini dapat dilaksanakan serta kepada Nandya Candra P S, Indra Dhea Nanda R, dan Karina Aprilia Wulandari yang telah membantu jalannya penelitian. 


\section{DAFTAR PUSTAKA}

Anonim. 2014. http://webcache.googleusercontent.com/search?q=cache:http://pudatin. setjen. pertanian.go.id/tinymcpuk/gambar/file/outlook_kakao_2014.pdf. Diakses pada Jumat, 24 Februari 2017.

Ginting, S. 2011. Mempelajari Pengaruh Lama Fermentasi dan Lama Penyangraian Biji Kakao Terhadap Mutu Bubuk Kakao. STEVIA, 1, 6-11.

Hu, Sujung; Kim, Byung Yong; and Baik, Moo Yoel. 2016. Physicochemical properties and antioxidant capacity of raw, roasted and puffed cacao beans. Food Chemistry, $194: 1089-1094$

Pusat Penelitian Kakao dan Kopi Indonesia. 2015. Kakao : Sejarah, Botani, Proses Produksi, Pengolahan, dan Perdagangan. Gadjah Mada University Press. Yogyakarta.

Sewet, Awad. 2004. Optimasi Kondisi Penyangraian untuk Menghasilkan Bubuk Kakao (Theobroma cacao L.) Dengan Sifat Fisik, Kimia, dan Organoleptik Terbaik. Skripsi. IPB.

SNI 01 - 3747 - 2009. Standar Nasional Indonesia: Kakao Bubuk. Badan Standardisasi Nasional. Jakarta 